\title{
Assessment of the Perspective of Emergency Department Medical Staff towards Professional Hazards at Selected Emergency Department Staff, Saudi Arabia
}

\author{
Dr.Jawzaa Saleh Allehyani \\ ER Resident, King Abdulaziz Hospital, Saudi Arabia
}

\begin{abstract}
Background: The peculiarity on patient protection in the arena of health care, hardly any organizations has evaluated the degree to which safety is a deliberate superiority or their culture manacles patient safety. In rejoinder to the Institute of Medicine's report and to an organizational commitment to patient safety, they conducted an efficient assessment of safety. Objectives: To assess the Perspective of Emergency Department Medical Staff towards Professional Hazards at Selected Emergency Department Staff, Saudi Arabia. Method: A cross-sectional survey was conducted at selected ER, Saudi Arabia. Self-administered questionnaire was provided to 200 Emergency Department Staff in the research setting based on their area of their medical specialties to assess the Perspective of Emergency Department Medical Staff towards Professional Hazards at Selected Emergency Department Staff, Saudi Arabia. Results: The findings showed that the Perception' towards Professional Hazards among some Emergency Department Staff working at selected ER was variable. The majority (92.3\%) of the Emergency Department Staff had a high level of Perception' towards Professional Hazards in relation to Professional Hazards " in relation to only contact with skin) washing with usual detergent is enough". On the other hand (75.2\%) of the Emergency Department Staff had a lowest level of Perception' towards Professional Hazards in relation to Blood spills should be cleaned up at the appointed time with sodium hypochlorite "Although, concerning the Intermittent Level of Perception' the highest level was Perception' towards Professional Hazards in relation to "Health care workers with non intact skin should not be involved in direct patient care until the condition resolves "(22.3\%). While, regarding the Low Level of Perception' towards Professional Hazards in relation to only contact with skin washing with usual detergent is enough" "was showed higher rate (16.4\%). Conclusions: The current study results revealed that there were high levels of Perception' among the Emergency Department Staff towards Professional Hazards within the study setting.
\end{abstract}

Keywords: Professional Hazards; Perspective \&Emergency Department Staff

\section{Introduction}

Increasingly, health care providers are apt conscious of the implication of transforming organizational culture in order to improve patient safety. Growing interest in safety culture has been accompanied by the need for assessment tools focused on the cultural aspects of patient safety development efforts. Safety culture assessment could be utilized as a tool for improving patient safety. It could also describe the characteristics of culture appraisal tools presently available and discusses their current and potential uses, including brief examples from healthcare organizations that have undertaken such assessments. (Kuo, 2013).

The capacities of putting into carry out in job-related and environmental health nursing has greatly expanded with increased emphasis on health promotion and health protection services. Many factors have influenced the evolution of occupational health practice. Among them are the changing population and workforce, the introduction of new chemicals and work processes into the work environment, increased work demands, technological advances and regulatory mandates, increased focus on illness/injury prevention, and a rise in health care costs and workers' compensation claims. (Ruben, et al., (2007).

Kuo .et al., (2006), mentioned that timely reporting of occupational exposures to an employee health service is required to ensure appropriate counseling, facilitate prophylaxis or early treatment, and establish legal prerequisites for workers' compensation. Failure to report exposures precludes interventions that could benefit the injured party, placing health care workers at unnecessary risk. Information is limited regarding the prevalence of needle stick injuries, the circumstances surrounding them, and the barriers to reporting them. We conducted this study to investigate the prevalence and context of needle stick injuries and behavior associated with the reporting of injuries among a large number of surgeons in training.

Hazards caused by non adherence to universal precautions by the health care providers, statistics reported by the Central Register of Occupational Diseases in Poland indicates that among 314 new cases of occupational diseases in HCWs in 2005, HBV and HCV represented $49.5 \%$ of all cases. Despite the substantial reduction in HBV infection since vaccination was introduced in 1989, the incidence of HCV hepatitis in Poland is still on the increase in this occupational group. (Rapiti, et al., 2005).

Emergency Department Staff should have a high level of Perception' about Professional Hazards enhance consciousness education has not been prominent among health care workers, particularly in developing countries. To the greatest of our understanding, the attentiveness of Emergency Department Staff in relation to knowledge and

\section{Volume 6 Issue 12, December 2017}




\section{International Journal of Science and Research (IJSR) \\ ISSN (Online): 2319-7064}

Index Copernicus Value (2016): 79.57 | Impact Factor (2015): 6.391

Perception' about policies of safety measures within the work setting. Consequently, conducted this study to assess the level of Perception' ' towards Professional Hazards among Emergency Department at Selected ER, Saudi Arabia.

\section{Participants and Methods}

This study was conducted in June, 2016 at selected ER the study was granted ethical approval by the Administrators Committee.

Administrators are the major teaching hospital, with approximately 450 beds. It provides services in community health, surgery, obstetrics and gynecology, pediatrics, psychiatry and general services. The number of sample size was 200 Emergency Department Staff was recruited for the study. The participants were selected from the Departments of Surgery, Intensive Care, and O.R at selected ER after signing an informed written consent form, the questionnaire was given to each participant. Before administration of the questionnaire, the purpose of the study was explained to each respondent and confidentiality of the information guaranteed.

The research was carried out by one of the authors who were appropriately trained in administering the informed consent and the self-report questionnaire to the participants. In this cross-sectional study, a structured questionnaire prepared by the authors, was administered to the participants.A32-item self-administered structured questionnaire about Perception' towards Professional Hazards among Emergency Department at Selected ER, Saudi Arabia. Was devised de novo and tested. It included a full range of response options,

designed to identify the practitioner's level of to assess their level Perception', towards Professional Hazards among Emergency Department Staff within the selected setting. Prior to distribution of the questionnaire, a pilot study was done on a selective group of health care workers who were asked to fill out the questionnaire and return it back with their remarks and criticism. Minor changes were then made to the final tool.

The preliminary part of the questionnaire consisted of demographic information such as occupation, age, gender, and the marital status. The second part of the questionnaire comprised of questions regarding their level of Perception' , towards Professional Hazards among medical staff. This part also assessed Perception' ' towards occupational injury. It took approximately 15 minutes to complete each appraisal.

The level of Perception' ' towards Professional Hazards among Emergency Department at Selected ER, Saudi Arabia. by examining questions. A score of " 1 " was assigned for a correct answer and " 0 " for an incorrect answer. A health care worker who obtained a total score of "5" was considered "very aware;" "4 or 3" "somewhat aware;" and "1 or 0" "not aware."The data were coded and analyzed by SPSS ${ }^{\circledR}$ for Windows ${ }^{\circledR}$ ver. 12.0. Strict confidentiality was maintained. All the data were stored in computers at a secured location, with access provided only to the researchers involved in the study. The $\chi 2$ test was used to test association between categorical variables. A p value $<0.05$ (two-tailed) was considered statistically significant differences.

\section{Results}

The Perspective level towards Professional Hazards among Emergency Department Staff at ER -Saudi Arabia

\begin{tabular}{|c|c|c|c|c|c|c|}
\hline \multirow[t]{2}{*}{ Items of Occupational Injury } & \multicolumn{2}{|c|}{ High Level of Perception } & \multicolumn{2}{|c|}{ Intermittent Level of Perception } & \multicolumn{2}{|c|}{ Low Level of Perception } \\
\hline & No & $\%$ & No & $\%$ & No & $\%$ \\
\hline $\begin{array}{c}\text { Professional Hazards " in relation to infectious } \\
\text { diseases }\end{array}$ & 159 & $72.1 \%$ & 11 & $8.1 \%$ & 35 & $16.4 \%$ \\
\hline $\begin{array}{c}\text { "Isolation is necessary for patients with blood-borne } \\
\text { infectious diseases " }\end{array}$ & 150 & $77.3 \%$ & 6 & $5.3 \%$ & 43 & $22.1 \%$ \\
\hline Utilizing Personal Protective Equipments & 161 & $79.2 \%$ & 16 & $6.5 \%$ & 31 & $15.3 \%$ \\
\hline $\begin{array}{l}\text { Professional Hazards " in relation to only contact with } \\
\text { skin) washing with usual detergent is enough" }\end{array}$ & 178 & $92.3 \%$ & 4 & $2.2 \%$ & 9 & $5.5 \%$ \\
\hline $\begin{array}{l}\text { Entire precautions are not necessary in situations that } \\
\text { might lead to contact with saliva" }\end{array}$ & 152 & $75.3 \%$ & 11 & $6.5 \%$ & 40 & $21.2 \%$ \\
\hline $\begin{array}{c}\text { "Health care workers with non intact skin should not } \\
\text { be involved in direct patient care until the condition } \\
\text { resolves " }\end{array}$ & 150 & $76.5 \%$ & 12 & $9.3 \%$ & 38 & $19.2 \%$ \\
\hline $\begin{array}{l}\text { Blood spills should be cleaned up at the appointed } \\
\text { time with sodium hypochlorite" }\end{array}$ & 143 & $71.5 \%$ & 13 & $3 \%$ & 53 & $29.5 \%$ \\
\hline
\end{tabular}

The findings showed that the Perception' towards Professional Hazards among some Emergency Department Staff working at selected ER was variable. The majority $(92.3 \%)$ of the Emergency Department Staff had a high level of Perception' towards Professional Hazards in relation to Professional Hazards " in relation to only contact with skin) washing with usual detergent is enough". On the other hand (75.2\%) of the Emergency Department Staff had a lowest level of Perception' towards Professional Hazards in relation to Blood spills should be cleaned up at the appointed time with sodium hypochlorite "Although, concerning the Intermittent Level of Perception' the highest level was Perception' towards Professional Hazards in relation to "Health care workers with non intact skin should not be involved in direct patient care until the condition resolves "(22.3\%).While, regarding the Low Level of Perception' towards Professional Hazards in relation to only contact with 


\section{International Journal of Science and Research (IJSR) ISSN (Online): 2319-7064}

Index Copernicus Value (2016): 79.57 | Impact Factor (2015): 6.391

skin washing with usual detergent is enough" "was showed higher rate $(16.4 \%)$

\section{Discussion}

The results showed that the Perception' towards Professional Hazards among some Emergency Department Staff working at selected ER was variable. The majority $(92.3 \%)$ of the Emergency Department Staff had a high level of Perception' towards Professional Hazards in relation to Professional Hazards " in relation to only contact with skin) washing with usual detergent is enough". On the other hand (75.2\%) of the Emergency Department Staff had a lowest level of Perception' towards Professional Hazards in relation to Blood spills should be cleaned up at the appointed time with sodium hypochlorite "Although, concerning the Intermittent Level of Perception' the highest level was Perception' towards Professional Hazards in relation to "Health care workers with non intact skin should not be involved in direct patient care until the condition resolves "(22.3\%).While, regarding the Low Level of Perception' towards Professional Hazards in relation to only contact with skin washing with usual detergent is enough" "was showed higher rate (16.4\%)

A further study reported by Guo, Shiao, Chuang,( 2003), involving 550 medical students and residents during the 1989-1990 training year likewise reported a high prevalence of needle stick injuries $(71 \%)$, and a higher frequency of injury (by a factor of 6) among surgical residents than among medical residents. In these two studies, rates of reporting needle stick injuries ranged from 9 to $19 \%$, and a more recent survey of all types of providers from an Iowa medical organization found that $34 \%$ had reported their exposure to an employee health service. On the other hand, the study carried by Regina (2002), showed that only $49 \%$ of surgical residents report such injuries extends previous observations that underreporting may result in a substantial underestimation of the magnitude of the problem.

Concerning the Intermittent Level of Perception' Intermittent Level of Perception' the highest level was Perception' towards Professional Hazards in relation to "Health care workers with non intact skin should not be involved in direct patient care until the condition resolves "(19.2\%).While, regarding the Low Level of Perception' towards Professional Hazards in relation to only contact with skin washing with usual detergent is enough" "was showed higher rate $(14.2 \%)$.It is very important that health care workers have good understanding about the risk of blood-borne pathogens at work place and about the preventive measures for reducing risk. In this study, the majorities of the respondents were very knowledgeable of the harmful effects of bloodborne pathogens and identified HIV as a potential harm followed by hepatitis and bacterial infections. In this study, health care workers employed in the health sector for longer periods were more aware of universal precautions compared with those who served for shorter periods. Training and education have been found to be of paramount importance to developing Perception' among health care workers, as well as improving adherence to high-quality clinical practice.
This research findings is congruent with the findings of the study carried out by (Rapiti, et al., 2005), who found that he greater Perception' of universal precautions among health care workers employed for a longer period non-compliance among medical doctors and nurses are associated with insufficient knowledge, workload, forgetfulness, workplace safety and the insight that colleagues also failed to track.

Personnel protective equipments reduce the risk of exposure of the health care provider's skin or mucous membranes to potentially infectious materials. Protective barriers reduce the risk of exposure to blood and other body fluids to which universal precautions apply. Examples of protective barriers include gloves, gowns, masks, and protective eyewear. Just over one half of the respondents indicated that they were provided with protective equipment most times. Furthermore, more nurses were provided with protective equipment than medical technologists and medical doctors. Interestingly, more respondents who were aware of universal precautions reported being provided with protective equipment more often than those who were somewhat or not aware. This study results congruent with the research data carried out by Pournaras, et al,2004, who reported that less than two-thirds of health care workers claimed that they always used personal protective equipment such as aprons, gowns and gloves, during surgeries and while conducting deliveries. According to Jawaid, et al, among medical doctors working in a tertiary care hospital in Pakistan, compliance for hand washing was $86 \%$, for wearing gloves was $79 \%$, masks $46 \%$, eye goggles $25 \%$ and for using gowns/plastic aprons was $45 \% .35$ However, there is sometimes a high rate of non-compliance among health care workers and this may be due to a lack of understanding among health care workers of how to properly use protective barriers.

The Current research showed that there was high level of Perception' towards Professional Hazards among Emergency Department Staff within the study setting. These findings suggest that training of health care workers to maintain and enhance their knowledge about occupational safety, blood borne pathogens and universal precautions could improve their use of universal precautions. Regular training should include the universal precautions, initial biohazard handling, safety policies, safety behavior, safety equipments, continuing monitoring and maintain continuous quality improvement concerning the practice of occupational safety.

\section{Acknowledgements}

Appreciation is hereby extended to all the participants and administrators staff at the Administrators, -Saudi Arabia.

\section{References}

[1] Peter, V, F.(2013). Safety culture assessment: a tool for improving patient safety in healthcare organizations. Westat, Research Blvd, Rockville, MD 20850, USA 


\section{International Journal of Science and Research (IJSR) \\ ISSN (Online): 2319-7064}

Index Copernicus Value (2016): 79.57 | Impact Factor (2015): 6.391

[2] Lacerda, Universal Precautions for Prevention of Transmission of HIV and Other Bloodborne Infections. accessed 22 December 2008, [http://www.cdc.gov/]

[3] Ustun Betta, Prüss-Ustün , Hutin Yuvan: Assessing the burden of disease from sharps injuries to healthcare workers at national and local levels. 2005, Geneva: World Health Organization, Environmental Burden of Disease Series, No 11

[4] Cathrine, Abed Abdullah, Strathdee Steffanie, Scott Paul, Botros Boulos, Safi Naquibullah, et al: HIV, hepatitis $\mathrm{C}$, and hepatitis $\mathrm{B}$ infections and associated risk behavior in injection drug users, Kabul, Afghanistan. Emerging Infectious Diseases Journal. 2007, 13: 1327-31.

[5] Kuo Irene, ul-Hasan Salman, Galai Noya, Thomas David, Zafar Tariq, Ahmed Mohaamad, Strathdee Steffanie: High HCV seroprevalance and HIV drug use risk behaviours among injection drug users in Pakistan. Harm Reduction Journal. 2006, 3: 26-10.1186/14777517-3-26.

[6] Rehman , Rasoul Mohammad, Wodak Allex, Claeson Mariam, Friedman Jed, Sayed Ghulam: Responding to HIV in Afghanistan. Lancet. 2007, 370: 2167-9. 10.1016/S0140-6736(07)61911-4.

[7] Guo YL, Shiao J, Chuang Y-C: Needlestick and sharps injuries among health-care workers in Taiwan. Epidemiology and Infection Journal. 2003, 122: 259-65. 10.1017/S0950268899002186.

[8] Regina Chan, Molassiotis Alexander, Eunica Chan, Virene Chan, Becky Ho, Chit-Ying Lai, et al: Nurses' knowledge of and compliance with universal precautions in an acute care hospital. International Journal of Nursing Studies. 2002, 39: 57-63.

[9] Pournaras S, Tsakris A, Mandraveli K, Faitatzidou A, Douboyas J, Tourkantonis A: Reported needlestick and sharps injuries among healthcare workers in a Greek general hospital. Occupational Medicine. 2004, 7: 4236. 10.1093/occmed/49.7.423.

[10] Lacerda RA. Infeccao hospitalar e sua relacao com a evolucao das practicas de assistencia a saude. In: Lacerda RA, ed. Controle de infeccao em centro cirurgico. Sao Paulo: Atheneu, 2003: 9-23.

[11] Lacerda RA, Egry EY. As infeccoes hospitalares e a sua relacao com o desenvolvimento da assistencia hospitalar: reflexoes para analise praticas atuais de controle. Rev Latinoam Enfermagem 1997;5:13-23.

[12] Beltrami EM, Williams IT, Shapiro CN, Chamberland ME. Risk and management of blood-borne infections in health care workers. Clin Microbiol Rev 2000;13(3):385-407.

[13] Gerberding JL. Incidence and prevalence of human immunodeficiency virus, hepatitis B virus, hepatitis C virus, and cytomegalovirus among health care personnel at risk for blood exposure: final report from a longitudinal study. J Infect Dis 1994;170(6):1410-7.

[14] Ruben FL, Norden CW, Rockwell K, Hruska E. Epidemiology of accidental needle-puncture wounds in hospital workers. Am J Med Sci 1983;286(1):26-30.

[15] Pruss-Ustun A, Rapiti E, Hutin Y. Estimation of the global burden of disease attributable to contaminated sharps injuries among health-care workers. Am J Ind Med 2005;48(6):482-90.
[16] Khuri-Bulos NA, Toukan A, Mahafzah A, et al. Epidemiology of needlestick and sharp injuries at a university hospital in a developing country: a

[17] Prospective study at the Jordan University Hospital, 1993 through 1995. Am J Infect Control 1997;25(4):322-9.

[18] Wang FD, Chen YY, Liu CY. Analysis of sharpedged medical-object injuries at a medical center in Taiwan. Infect Control Hosp Epidemiol 2000;21(10):656-8.

[19] Pruss-Ustun A, Rapiti E, Hutin Y. Sharp injuries: global burden of disease from sharp injuries to health care workers Geneva, Switzerland. World Health Organization, 2003.

[20] Orji EO, Fasubaa OB, Onwudiegwu U, et al. Occupational health Hazards among health care workers in an obstetrics and gynaecology unit of a Nigerian teaching hospital. J Obstet Gynaecol 2002;22(1):75-8.

[21] Recommendations for protection against viral hepatitis. MMWR Morb Mortal Wkly Rep 1985;34(22):313-24, 329-35.

[22] Recommendations for preventing transmission of infection with human T-lymphotropic virus type III/lymphadenopathy-associated virus in the workplace. MMWR Morb Mortal Wkly Rep 1985;34(45):681-6, 691-5.

[23] McCarthy GM. Universal Precautions J Can Dent Assoc 2000;66:556-7.

[24] Update: human immunodeficiency virus infections in health-care workers exposed to blood of infected patients. MMWR Morb Mortal Wkly Rep 1987;36(19):285-9.

[25] Acquired immunodeficiency syndrome (AIDS): precautions for health-care workers and allied professionals. MMWR Morb Mortal Wkly Rep 1983;32(34):450-1.

[26] Garner JS. Hospital Infection Control Practices Advisory Committee. Guideline for isolation precautions in hospitals. Infect Hosp Epidemiol 1996; 17:53-80.

[27] Spire B, Barre-Sinoussi F, Montagnier L, Chermann JC. Inactivation of lymphadenopathy associated virus by chemical disinfectants. Lancet 1984;2(8408):899901.

[28] Martin LS, McDougal JS, Loskoski SL. Disinfection and inactivation of the human $\mathrm{T}$ lymphotropic virus type III/Lymphadenopathy-associated virus. J Infect Dis 1985;152(2):400-3.

[29] McDougal JS, Martin LS, Cort SP, Mozen M, Heldebrant CM, Evatt BL. Thermal inactivation of the acquired immunodeficiency syndrome virus, human $\mathrm{T}$ lymphotropic virus-III/lymphadenopathy-associated virus, with special reference to antihemophilic factor. $\mathbf{J}$ Clin Invest 1985;76(2):875-7.

[30] Olowu O, Oluaje E, Kehinde O. Knowledge and practice of universal precautions among final year medical and dental students in the University College of Ibadan. Dokita 2001;28:6-9.

[31] Odujurin OM, Adegoke OA. AIDS: Perception' and blood handling practices of health care workers in Lagos. Nig J Epidl 1995;11(4):425-30. 
[32] Palenick C. Strategic planning for infection control. J Canadian Dental Association 2000;66:556-7.

[33] Danchaivijitr S, Tantiwatanapaiboon Y, Chokloikaew $\mathrm{S}$, et al. Universal precautions: knowledge, compliance and attitudes of doctors and nurses in Thailand. J Med Assoc Thai 1995;78 Suppl 2:S112S117.

[34] Twitchell K. Bloodborne pathogens: what you need to know-Part I. Journal of the American Association of Occupational Health Nurses 2003;51:46-7.

[35] Godin G, Naccache H, Morel S, Ebacher MF. Determinants of nurses' adherence to universal precautions for venipunctures. Am J Infect Control 2000;28(5):359-64.

[36] Stein AD, Makarawo TP, Ahmad MFR. A survey of doctors' and nurses' knowledge, attitudes and compliance with infection control guidelines in Birmingham teaching hospitals. Journal of Infection Control 2003;54:68-73.

[37] Trim JC, Adams D, Elliott TS. Healthcare workers' knowledge of inoculation injuries and glove use. $\mathrm{Br} \mathrm{J}$ Nurs 2003;12(4):215-21.

[38] Rana JS, Khan AR, Haleem AA, et al. Hepatitis C: knowledge, attitudes and practices among orthopedic trainee surgeons in Pakistan. Ann Saudi Med 2000;20(5-6):477-9.

[39] Wang H, Fennie K, He G, et al. A training programme for prevention of occupational exposure to bloodborne pathogens: impact on knowledge, behaviour and incidence of needle stick injuries among student nurses in Changsha, People's Republic of China. J Adv Nurs 2003;41(2):187-94.

[40]Heinrich J. Occupational Safety: Selected cost and benefit implications of needle stick prevention devices for hospitals (letter to House of Representatives from US General Accounting Office), 2000.

[41] Gerberding JL. Clinical practice. Occupational exposure to HIV in health care settings. N Engl J Med 2003;348(9):826-

[42] Connington A. Has the point been made? a needlestick injury Perception' survey. Safe Gard Medical 2002.

[43] Alam M. Knowledge, attitude and practices among health care workers on needle-stick injuries. Ann Saudi Med 2002;22(5-6):396-9.

[44] Sadoh WE, Fawole AO, Sadoh AE, et al. Practice of universal precautions among healthcare workers. J Natl Med Assoc 2006;98(5):722-6.

[45] Jawaid M, Iqbal M, Shahbaz S. Compliance with standard precautions: a long way ahead. Journal of Public Health 2009;38:85-8.

[46] Evanoff B, Kim L, Mutha S, et al. Compliance with universal precautions among emergency department personnel caring for trauma patients. Ann Emerg Med 1999;33(2):160-5.

Volume 6 Issue 12, December 2017

www.ijsr.net

Licensed Under Creative Commons Attribution CC BY 